\title{
Discussion and Analysis of Internet Plus Finance Mode
}

\author{
Wei $\mathrm{Hu}^{1}$, Jing $\mathrm{Gao}^{2}$ \\ Information School of Capital University of Economics and Business, Beijing, China
}

\begin{abstract}
Since then, the Internet finance has entered the golden age of rapid development. This article is based on the above background, introduces concept and connotation of the Internet financial,development model and challenges systematically, and explores the difference between Internet financial and financial Internet. In China's high-speed development of economic and social background, we put forward the development trend of Internet plus finance in the future.
\end{abstract}

Keywords-Internet plus Finance, Financial Supervision, Financial Risk

\section{I、INTRODUCTION}

Since 2013, the term Internet financial popular across all over the world. Even Premier Li Keqiang said in the 2015 government work report :We would develop the "Internet Plus" action plan to integrate mobile Internet, cloud computing big data, and the Internet of Things with modern manufacturing, to encourage the healthy development of e-commerce, industrial networks, and Internet banking, and to get Internet-based companies to increase their presence in the international market. In 2016 the government work report, prime minister likeqiang has repeatedly mentioned tothe use of "Internet plus" power to further deepen reform and play a public entrepreneurship and innovation, and the "Internet plus" set Trimaran Huizhong force multiplier effect. On May 24,

\footnotetext{
${ }^{1}$ Wei Hu (1992—), First year graduate student, Research Field: Data mining, Internet banking

${ }^{2}$ Jing Gao (1977-), Master Tutor , Associate Professor, Research Field: Data mining, Computer architecture
}

2016, premier Li Keqiang attended the China big data industry summit and expounded on the Internet plus again.He said that the current Chinese economy was at a critical stage of transformation and upgrading. The booming development of Big data, cloud computing and other cutting-edge technology and sharing economy, was conducive to the development of the new economy and foster new momentum. We would promote the integration ofdata, "Internet plus" and manufacturing, transform and upgrade traditional industries, and promote transformation and upgrading of China's economy, to maintain high-speed growth, towards the high-end level. "Internet plus" is not only the Internet-based traditional industries, but also the Internet industry with traditional industries such as manufacturing, finance,to conduct a comprehensive, in-depth cross-border integration.About "Internet plus", The back of "plus" is traditional industries, In China's Internet development in the past nearly 30 years, the combination of Internet and advertising, retail, banking, telecommunications and other traditional industries has created Baidu, Alibaba, Jingdong, Alipay, Tencent and other Internet outstanding enterprises, but also provided a new path and valuable experience for China's economy upgrade.

\section{Internet plus finance and traditional finance}

\section{A. The connotation of Internet plus Finance \\ At present, the academia and the business community has been on the "Internet plus " meaning the basic agreement. From a technical}


point of view, "Internet plus" is the use of all walks of life to boost the development of Internet technology, the Internet thinking, the Internet platform. The core technology of "Internet plus--big data, cloud computing, mobile Internet technology, networking technology, not only is an important technical support for the network economy era, but also is an important tool of the realization for commodity trading "on-line" and "data",and also is an important tool for information processing in the information age. Therefore,the traditional industry "Internet plus" process means a new capacity, technology application and innovation are the core content, and Cloud computing, big data and other information on the process of innovation, user innovation, service innovation, marketing innovation is essential ${ }^{[1]}$.

However, the domestic academic did not give official connotation of the Internet plus finance, as opinions vary, no unanimous conclusion can be drawn. However, some definition of Internet plus finance given by scholars worth learning.

Cong $\mathrm{Wu}$ regarded that "Internet plus finance" combines the concept of traditional culture which is basing on thetradition and making innovations, both the "Internet to transform traditional finance", namely Finance Internet, but also including the Internet finance new formats and new evolution, that is, combining Internet banking and Finance Internet to create homologous symbiosis, complementarity, cooperation and win-win of the new financial system ${ }^{[2]}$. .

There are some scholars believe that the "Internet plus finance" is a combination of Internet technology and finance. This combination consists of three main ways: the first one is the internet company doing financial; if such a large-scale phenomenon occurs, and replace the original financial firms, is called financial subversion on the Internet.The second one is the Internet-based financial institutions.
The third one is the cooperation between Internet companies and financial institutions [3]. Today,with the rapid development of the Internet plus finance,there are Internet plus insurance, Internet plus guarantee, Internet plus finance, Internet plus small loans, Internet plus payment, Internet plus bank, Internet plus crowdfunding, Internet plus securities, Internet plus currency and other forms in the market.

Manucher Shahrokhi pointed that the Internet banking is the third financial model after the traditional financial intermediation and capital markets, it can reduce transaction costs and improve the transparency of financial information, and also can improve the efficiency of financial institutions to handle business, which need highly demand for information technology and have to ensure the safety and reliability of the technology ${ }^{[14]}$.

\section{B. Compared with Internet banking,traditional finance and financial Internet}

Statement about "Internet plus" combined with financial statement in academia are different. There are three versions: "Internet plus Finance", Internet banking, and Finance Internet. Whether it is "Internet plus Finance", Internet banking or Finance Internet, in essence, it involves the problem of combining banking and the Internet, just has different footing and leader.About the Internet financial category definition, domestic scholars have two kinds of views:one view is Internet banking, it is the Internet companies engage in financial activities and use the application of Internet technology to the financial sector,is the floorboard of network financial products.And it is completely different from the traditional mode of financial (banking, securities, insurance),mainly it has lower cost, higher efficiency than the traditional financial and also has no limit of time and space. Internet banking is the subversion of traditional financial, its main patterns are third-party payment, P2P loans, crowdfunding, electricity small loans, 
virtual currency, etc. ${ }^{[4]}{ }^{[5]}$, this part specifically belongs to special Internet financial category. Another view based on system theory, suggest that the emerging network finance and the traditional financial belongs to a financial system, they are not independent, but the development relationship of mutual fusion and mutual promoting. Network financial belongs to online financial model, but also need to use traditional financial institutions to carry out off-line financial activities. On the other hand, in the Internet age, the traditional financial also should comply with the trend and carry the financial business to the Internet, traditional financial is the inevitable trend of the development of the Internet. As a result, the Internet financial includes Internet enterprise financialization of emerging financial network, and also includes online banking business of traditional financial Internet, this is the Internet generalized financial category ${ }^{[6]}$.

Some scholars stated that as the Internet and combination of financial deepening, Traditional financial continue to extend to the internet, financial services carried out by Internet companies also continue to penetrate the offline financeal, and boundary of traditional financial and Internet financial business will no longer obvious, cross-border development will be the future trend in the development of financial industry ${ }^{[7]}$. Between 2001 and 2002, the New York fed, the Basel committee, the world bank and international monetary fund has held several rounds of seminar on e-finance development, scholars deeply discusses the fusion problems of Internet technology and the traditional financial sector from different aspects . Sato and Haokins, Allen and Schaechter comprehensively summarized the study of the Internet banking from all parties. Visible from the literature in this period, despite the U.S. from all walks of life for Internet financial can subvert the traditional finance model has certain dispute, the mainstream view is that the emerging financial mode based on Internet technology and the traditional financial will be the relationship between integration and competition ${ }^{[13]}$. But the Internet finance is based on traditional financial, not a substitute for the traditional finance. The cooperation between Internet finance and traditional financial will be bigger than the competition.

\section{III the main mode of Internet plus financial}

Nowadays internet banking is developing rapidly,Internet financial model innovation become the key to the healthy and sustainable development of Internet banking.With the rapid development of big data, cloud computing, Internet banking model is constantly emerging.

In European countries,the main mode of Internet financial can be divided into six kinds: Internet payment, P2P network lending, crowd funding financing, Internet banking, Internet security and Internet insurance, etc.

Peng Zhaodong considered that the general pattern of domestic Internet banking mainly has the third party payment, P2P and crowdfunding. He also proposed that the domestic Internet banking enterprise are four modes, namely, the Internet giant mode, mode of financial institutions, operators mode and financial industry mode ${ }^{[8]}$.

At present, the public generally agree that there are six major Internet financial platform model, as shown in Tab.3-1: 


\begin{tabular}{|c|c|c|c|}
\hline mode & Specific meaning & $\begin{array}{l}\text { national representa- } \\
\text { tive }\end{array}$ & $\begin{array}{c}\text { Foreign representa- } \\
\text { tive }\end{array}$ \\
\hline $\begin{array}{l}\text { The } \\
\text { third-party } \\
\text { payment plat- } \\
\text { form }\end{array}$ & $\begin{array}{l}\text { Online payment platform operated by non-bank of } \\
\text { third party organizations }\end{array}$ & $\begin{array}{l}\text { Alipay, YeePay, } \\
\text { TenPay, etc. }\end{array}$ & $\begin{array}{l}\text { PayPal, Google } \\
\text { Wallet in US, } \\
\text { Worldpay in UK, } \\
\text { etc. }\end{array}$ \\
\hline $\begin{array}{l}\text { P2P net loan } \\
\text { platform }\end{array}$ & $\begin{array}{l}\text { Intermediary Connecting borrowers and inves- } \\
\text { tors } \\
\text {,matched by lending platform, the platform only } \\
\text { provides service and audit to meet the needs of } \\
\text { investors and borrowers }\end{array}$ & $\begin{array}{l}\text { Angel Plan, Yooee } \\
\text { loan, Zhongbao } \\
\text { Investmen, } \\
\text { etc. }\end{array}$ & $\begin{array}{l}\text { Lending Club in } \\
\qquad \text { US, } \\
\text { Auxmoney in } \\
\text { Germany, Aqush in } \\
\text { Japan, etc. }\end{array}$ \\
\hline $\begin{array}{l}\text { e-commerce } \\
\text { Finance }\end{array}$ & $\begin{array}{l}\text { e-commerce Finance is by extracting the history } \\
\text { of e-commerce transactions and other external } \\
\text { date to form big data,and use the advanced tech- } \\
\text { nology such as cloud computing and so on, under } \\
\text { the condition of the controllable risk, when con- } \\
\text { sumers, suppliers of funds shortage and financing } \\
\text { needs, e-commerce platform to provide a guaran- } \\
\text { tee, the funds will be provided to the demand side }\end{array}$ & $\begin{array}{l}\text { Alibaba, jingdong } \\
\text { mall and Sun- } \\
\text { ing,etc. }\end{array}$ & Amazon,etc. \\
\hline Crowdfunding & $\begin{array}{l}\text { Through the } \mathrm{P} 2 \mathrm{P} \text { or } \mathrm{P} 2 \mathrm{~B} \text { platform of the protocol } \\
\text { mechanism to make financing people obtain fi- } \\
\text { nancing from different individuals }\end{array}$ & $\begin{array}{l}\text { AngelCrunch, } \\
\text { Crowdfunding net- } \\
\text { work }\end{array}$ & $\begin{array}{l}\text { Crowdcube in UK, } \\
\text { Fundable, Kick- } \\
\text { starter and Indie- } \\
\text { GoGo in US } \\
\text {, etc. }\end{array}$ \\
\hline ING Direct & $\begin{array}{l}\text { Make full use of modern information technology, } \\
\text { with the help of the Internet to carry out finan- } \\
\text { cial business and use offline and online combin- } \\
\text { ing ways to finance the business }\end{array}$ & $\begin{array}{l}\text { WeChat bank } \\
\text {,etc. }\end{array}$ & $\begin{array}{l}\text { ING Direct USA in } \\
\text { Holland, } \\
\text { FirstDirect bank in } \\
\text { UK, etc. }\end{array}$ \\
\hline Yu Ebao & $\begin{array}{l}\text { Online financial management, through the plat- } \\
\text { form to provide all kinds of financial investment } \\
\text { and be convenient for user to invest online }\end{array}$ & $\begin{array}{c}\text { BaiduBaifa, WeChat } \\
\text { CAITONG, etc }\end{array}$ & Paypal in US, etc. \\
\hline
\end{tabular}

Tab.3-1 Internet financial model

\section{A. The third-party payment platformmode}

According to Iresearch statistical data obtained third-party Internet transaction size in 2011-2015 and the year-on-year growth rate, third-party Internet prediction transaction size in 2016-2019 and forecast year-on-year growth rate, specific information as shown in Fig.3-1, China's third-party Internet payment transaction scale amounted to 11.86745 trillion yuan in 2015 , up $46.9 \%$ year on year, growth has slowed. By analyzing the current situation, we think the main reason for the growth slowed is due to the rapid development of mobile Internet, mobile end their convenience allowing users to gradually migrate to mobile terminals,and currently the Internet giant, traditional institutions flocked in the field of mobile Internet speeding up the transfer speed of the user. According to statistics, by 2015, According to statistics, in 2015 Alipay mobile payment users accounted for more than half, the proportion reached 65\%,and we make combination of the mobile payment and Internet payment 
and provide full payment of financial services achieved good results.

for the users, I believe that in the future it will be

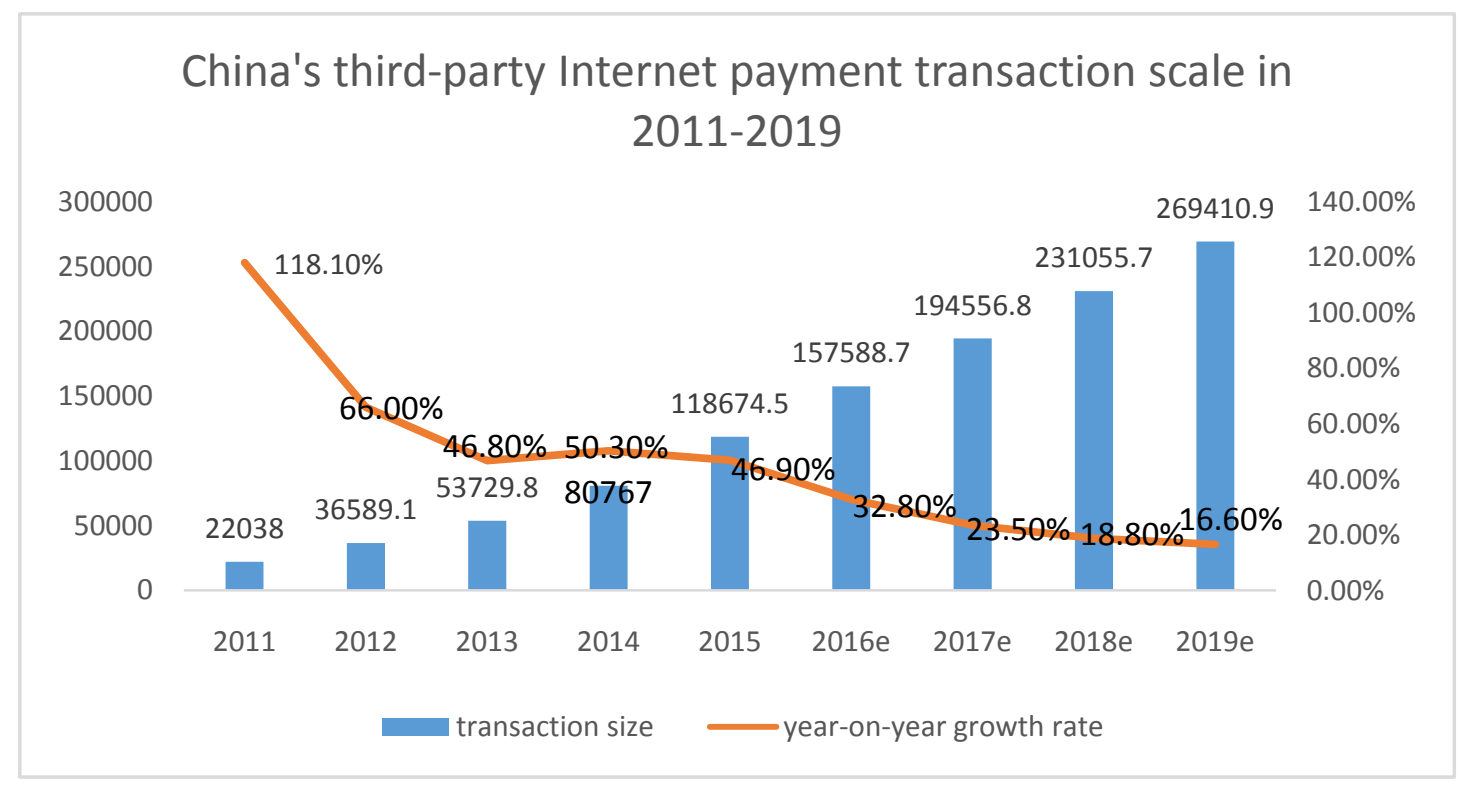

Fig.3-1 China's third-party Internet payment transaction scale in 2011-2019

\section{B. P2P net loan platformmode}

On the basis of the net loan home data analysis P2P net loan operations platform comprehensive statistics from the beginning to 2014,specific information as shown in Tab.3-2.Before 2012, the P2P network development was relatively slow and the number of loan operation platforms only was 50,afterwards the P2P network development expanded exponentially. Until the end of 2014, it existed 1575 operating platform; loans balance developed from
1.3 billion yuan before 2012 to 103.6 billion yuan in 2014, the scale enlarged 80 times; the current number grew from 28000 to 1.16 million, the current number of loans increased from 08000 to 630000, participants increased 50 times. At the same time, net loan problems were also appears more and more frequently, the number of questions arise platform rose annually,and increased from 10 in 2012 prior to 367 in 2014 ,of which the vast large number of event types is fraud on foot.

Tab.3-2 P2P net loan operation platform Comprehensive statistics

\begin{tabular}{|c|c|c|c|c|c|c|c|c|}
\hline Time(year) & $\begin{array}{l}\text { Turnover } \\
(100 \\
\text { million } \\
\text { yuan) }\end{array}$ & $\begin{array}{l}\text { Number of } \\
\text { Operating } \\
\text { platform }\end{array}$ & $\begin{array}{l}\text { Number of } \\
\text { current } \\
\text { problems } \\
\text { platform } \\
\text { (unit ) }\end{array}$ & $\begin{array}{l}\text { Number of } \\
\text { Cumulative } \\
\text { problems } \\
\text { platform } \\
\text { (unit) }\end{array}$ & $\begin{array}{l}\text { Loan } \\
\text { balance } \\
\text { (100 } \\
\text { million } \\
\text { yuan) }\end{array}$ & $\begin{array}{l}\text { Consolidated } \\
\text { interest } \\
\text { rate(\%) }\end{array}$ & $\begin{array}{l}\text { number of } \\
\text { the current } \\
\text { investment } \\
\text { (ten thou- } \\
\text { sand) }\end{array}$ & $\begin{array}{l}\text { number of } \\
\text { current bor- } \\
\text { rowers(10 } \\
\text { thousand) }\end{array}$ \\
\hline before2012 & 31.00 & 50 & 10 & 10 & 13.00 & 18.90 & 2.80 & 0.80 \\
\hline 2012 & 212.00 & 200 & 6 & 16 & 56.00 & 19.13 & 5.10 & 1.90 \\
\hline 2013 & 1058.00 & 800 & 76 & 92 & 268.00 & 23.05 & 25.00 & 15.00 \\
\hline 2014Q1 & 363.37 & 1023 & 27 & 119 & 381.00 & 20.78 & 36.46 & 8.79 \\
\hline 2014Q2 & 483.23 & 1184 & 29 & 148 & 477.00 & 19.41 & 45.04 & 11.48 \\
\hline 2014Q3 & 729.20 & 1438 & 49 & 197 & 646.00 & 17.46 & 76.12 & 24.79 \\
\hline 2014Q4 & 952.37 & 1575 & 170 & 367 & 1036.00 & 16.26 & 93.38 & 33.85 \\
\hline 2014 & 2528.00 & 1575 & 275 & 367 & 1036.00 & 17.86 & 116.00 & 63.00 \\
\hline
\end{tabular}




\section{E-commerce Finance mode}

The difference between the e-commerce Finance and traditional finance mainly lies in: the first aspect is different medium adopted by the financial business, the second aspect is the financial participants know that the Internet "openness, equality, cooperation, share" of nature,through the network platform,to make the traditional financial business become more transparent,more collaborative, more participation,lower intermediate cost,more convenient.With Internet technology as the core, expanding the small micro enterprise financing channels can better solve the effective use of social idle funds.With the development of science and technology, e-commerce finance will be rapid development to make our life and work great changes.

\section{Crowdfunding}

According to incomplete results, particularly as of December 31, 2015, there were the normal operation of crowdfunding platform 283 (excluding on-line test platform).on the basis of Ying Chan consulting data we can see the total amount of successful crowdfunding industry financing over the years, as shown in Fig.2-2. Crowd funding industry was rapid growth in 2014 and 2015, even the total amount of successful crowdfunding industry financing breakthrough billion mark in 2015, year-on-year growth of $429.38 \%$ in 2014 .As can be seen, crowdfunding industry usher in the golden period of rapid development, and all kinds of crowdfunding models continue to progress, I believe the reward crowd funding the will become a new consumption pattern in the future.

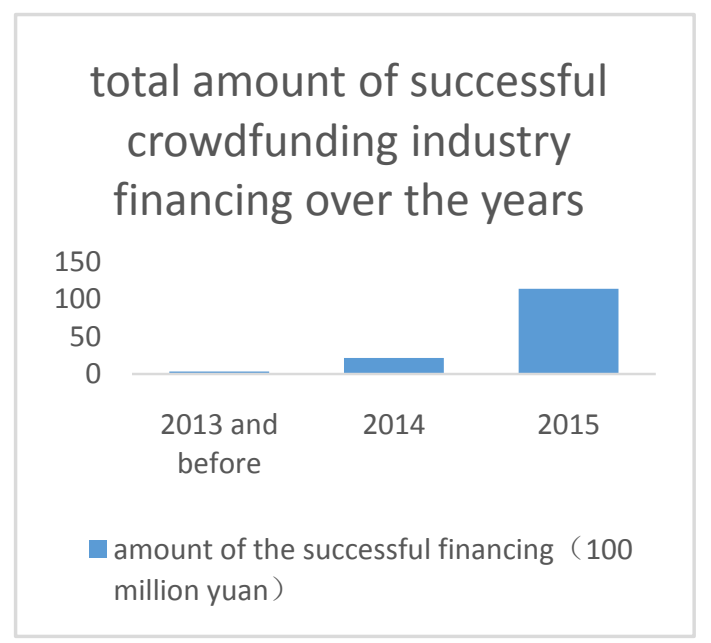

Fig. 2-2 amount of successful crowdfunding industry financing over the years

\section{E. ING Direct mode}

As of March 1, 2016, China has launched a number of 55 direct banking service of commercial banks, participants are mostly joint-stock commercial banks and city commercial banks.Direct current bank products can be divided into three types: one is the financial management products, including class of Yu Ebao, P2P finance, Bill financing, bank financing; the second is the traditional deposit and lending business products, including deposits, loans and remittances; the third is other products, including funds, gold,silver, and insurance. Combined with domestic and foreign experience of exploration and practice, direct bank still has broader space for development in the current financial environment of the Internet.Both opportunities and challenges of the moment,if we clarify development ideas and sum up experience and lessons, direct bank would go further.

\section{F. Yu Ebao mode}

According to the China Electronic Commerce Research Center (100EC.CN) monitoring data show that as of July 2015 Tencent financial business transaction size had exceeded 150 billion, the number of users had more than 16 million ,six or seven two months of users net growth was nearly 30\%.Yu Ebao transactions 
reached 711.7 billion yuan in the end of the first quarter of 2015, increased 132.8 billion yuan relative to the end of 2014, and had an qoq increase of 23\% .Although the Yu Ebao mode occupy a certain market share, but its profit decline and lack of stamina attracted users strong dissatisfaction, coupled with intense competition from other Internet financial products to make massive money outflows and also make size shrunk. Therefore the Yu Ebaolost earnings advantage in order to survive in the cracks, it must be based on the moment and focus on the future to establish their own advantages and seek long-term development.

\section{IV 、 Internet financial challenges and the future}

In recent years, Internet banking has been the hot development, in addition to big data, cloud computing technology development to provide rapid development opportunities, but as a new thing, is also facing a variety of challenges, mainly in the blind pursuit of Internet financial model, lack of innovation, the risks of Internet banking development,the lack of technical regulation ${ }^{[9]}$. The risks of Internet banking mainly in the following aspects:

1) lack of supervision and inadequate legal. Currently the main target of laws and regulations in China's financial sector is the traditional finance, it can't fit the unique characteristics of the Internet banking and Internet banking industry is "three noes" status,specifically is no threshold, no standards, no regulatory, and it is a fine line between "legal" and " illegal ".So lack of supporting regulatory requirements brings lots of risks of Internet banking ${ }^{[10][11]}$.

2) The security risk. Internet financial security problems are mainly the client's capital security, information security and system security.In the face of big data characteristics of the Internet, the safety of the sensitive data and data volume increase puts forward the challenge to
Internet financial security ${ }^{[12]}$.

3) The market security. Internet banking still has inherent traditional financial risks.Market turmoil,competitive pressure, enterprises blindly pursuing,lack of innovation, credit problems, and so on are all existing problems needed to resolve.

4) The liquidity risk. The investment period of Internet financial product is longer,and the liability period is shorter, once the debt maturity can't be rolled on time, funding liquidity risk can occur.

Although the Internet financial risks remain, the challenge is inevitable and the future can't be determined, the Internet is ushering in the financial best period of development, the scale of the Internet continues to expand.In order to better promote the healthy development of Internet banking, it is necessary to encourage financial innovation and achieve business model innovation and differentiation, at the same time,it must improve Internet banking laws and regulations,establish relevant regulatory agencies,regulate the Internet business model, and correctly handle the relationship between the supervision and encouraging innovation.In the future,only the Internet banking plus innovation plus security is sustainable development trend of Internet banking. Now we have entered the era of $4 \mathrm{G}$,the era of mobile internet financial accelerating has arrived, the transforming from Internet banking into mobile Internet banking is irreversible,and the prospects for mobile Internet financial development are vast. I believe,that it will be very important trend and great opportunity to the future.

\section{Acknowledgment}

Thanks are due to Ms. Gao for valuable discussion and thanks to Iresearch, net loan home, Ying Can consulting for giving me the data. 


\section{References}

[1] Kai Yang, Sermon "Internet plus", East China science and Technology, 2015(4):35-43

[2] Cong $\mathrm{Wu}$, "Internet plus finance" to promote the development of China's financial system, Development Finance Research.2015(4):48-55

[3] Haixia Yang, Internet banking improve financial efficiency?, China investment.2014

[4] Ping Xie and Chuanwei Zou, Internet financial model research.Financial research,2012(12):15-26

[5] Gang Zeng,Positive attention on the characteristics and development of the Internet banking -- based on the theory of monetary and financial perspective,The banker,2012 (11):11-13

[6] Mingzhe Zhang,The basic characteristics of the Internet finance,Regional finance research,2013(12 ):13-16

[7] Jing Zhang,Internet banking: emerging formats, potential risk and response,Explore the Economic Issues,2014 (4):81-85

[8] Zhaodong Peng,Research of "Internet plus finance" development pattern,Management to explore,2014(4)

[9] PingXie,Internet Financial regulation can not only depend

people[EB],http://finance.chinaso.com/detail/20160322 $/ 100$

0200032880141458650613507063323_1.html

[10] Research group of Jiangsu branch of ICBC,Discussion on legal risk management of online banking[J],Financial Forum, 2010(12): 61-67

[11] Weirong Yan,BoceHao and Juan Li,A preliminary study on the construction of China's network financial risk supervision model[J],Economic Research Guide,2013(6):69-70

[12] Feng Zhang,Research on the technical risk and prevention of network bank transaction[J],Finance and economy, 2010(3): 30-32

[13] Allen.H, Hawkins.Jand Sato.S, Electronic Trading and Its Implications for Financial Systems[R], BIS PapersChapters with Number 07-04, November,200

[14] ManucherShahrokhi, Journal of Banking \& Finance [M], American: Wiley,2008:365-39 